\title{
PENGARUH KEPUASAN KERJA DAN KOMITMEN \\ ORGANISASI TERHADAP ORGANIZATIONAL CITIZENSHIP BEHAVIOR (OCB) PADA DINAS PENANAMAN MODAL DAN PELAYANAN TERPADU SATU PINTU (DPMPTSP) KOTA PADANG
}

\author{
Reva Yolanda, Zusmawati \\ STIE "KBP" PADANG \\ Yolandareva467@gmail.com
}

\begin{abstract}
ABTRACT
This study aims to examine the effect of job satisfaction and organizational commitment on organizational citizenship behavior (OCB) in the Dinas Penanaman Modal and Pelayanan Terpadu satu Pintu (DPMPTSP) of Padang City. The data used in this study are primary data obtained from the questionnaire. The number of samples is 40 respondents where the number of samples is equal to the number of population so that the total sampling technique is used for sampling. The analysis technique used is a multiple linear regression method and hypothesis testing using the $t$ test (partial). The results showed that the Job Satisfaction variable had no effect and was not significant for $O C B$ with the acquisition of the calculated $t$ value of $0.443<t$ table 1.687, and the sig value of $0.660>0.05$. While the organizational commitment variable has a positive and significant effect on $O C B$, with the acquisition of $t$ count equal to $9.325<t$ table 1.687, and the value of sig 0,000>0.05. This means that the willingness of employees to conduct OCB behavior is based more on their commitment to the Dinas Penanaman Modal and Pelayanan Terpadu satu Pintu (DPMPTSP) of the padang city than their job satisfaction.
\end{abstract}

Keywords: Job Satisfaction, Organizational Commitment, and Organizational Citizenship Behavior (OCB).

\section{PENDAHULUAN}

Perkembangan industri perusahaan yang bergerak pada bidang pelayanan jasa sangat pesat, menyebabkan persaingan bisnis instansi menjadi sangat tajam, baik di pasar domestik maupun pasar internasional. Perusahaan ini merupakan instansi penyedia pelayanan jasa dan pemberian izin usaha pada perdagangan masyarakat yang melaksanakan tugas dan fungi peninjauannya yakni adalah Dinas Penanaman Modal dan Pelayanan Terpadu Satu Pintu kota Padang. Bagi instansi penyedia jasa, kualitas pelayanan adalah faktor terpenting yang mempengaruhi kepuasan pelanggan. Meningkatnya intensitas persaingan dan jumlah pesaing menuntut perusahaan untuk selalu memperhatikan kebutuhan dan keinginan konsumen serta berusaha memenuhi harapan konsumen dengan cara memberikan pelayanan yang lebih memuaskan dari pada yang dilakukan oleh pesaing. Dengan 
demikian, hanya perusahaan yang berkualitas yang mampu bersaing dan menguasai pasar (Djati, 2017).

Perilaku extra-role dalam organisasi juga dikenal dengan istilah organizational citizenship behavior (OCB), dan orang yang menampilkan perilaku OCB disebut sebagai karyawan yang baik (good citizen). Organizational Citizenship Behavior (OCB) adalah sikap membantu yang ditunjukkan oleh anggota organisasi, yang sifatnya konstruktif, dihargai oleh perusahaan tetapi tidak secara langsung berhubungan dengan produktivitas individu, contohnya adalah membantu rekan kerja, sukarela melakukan kegiatan ekstra di tempat kerja, menghindari konflik dengan rekan kerja, melindungi properti organisasi, menghargai peraturan yang berlaku dalam organisasi, toleransi pada situasi yang kurang ideal/menyenangkan, memberi saran yang membangun di tempat kerja, serta tidak membuang-buang waktu ditempat kerja (Seniati, 2004).

Organizational Citizenship Behavior (OCB) dapat timbul dari berbagai faktor dalam organisasi, diantaranya karena terdapat kepuasan kerja dari karyawan dan komitmen organisasi yang tinggi (Robbin \& Judge, 2007). Ketika karyawan merasakan kepuasan terhadap pekerjaan yang dilakukannya, maka karyawan tersebut akan bekerja secara maksimal dalam menyelesaikan tugasnya, bahkan melebihi beberapa hal yang mungkin di luar tugasnya. Begitu juga ketika seseorang mempunyai komitmen yang tinggi terhadap organisasi, maka orang tersebut akan melakukan apapun untuk memajukan perusahaan karena keyakinannya terhadap organisasi tersebut (Luthans, 1995) Selain kepuasan kerja, komitmen organisasi merupakan variabel yang mempengaruhi OCB dalam pencapaian keunggulan kondisi kerja yang optimal. Komitmen organisasi merupakan salah satu usaha dalam menangani gejala kerja yang negatif (Darmawati, 2013).

Berdasarkan hasil pengamatan yang didapat penulis, bahwa pada instansi ini ditemukan masalah yang sering muncul berkaitan dengan indikasi masih rendahnya perilaku OCB karyawan pada DPMPTSP kota Padang, ditandai dengan pekerjaan yang dilakukan secara sukarela seperti menolong rekan kerja yang kerepotan dalam tugasnya, menggantikan tugas rekan kerja yang tidak masuk atau cuti istirahat tetapi belum mendapatkan promosi atas apa yang telah dilakukan, memberikan perhatian khsusus terhadap pertemuan yang dianggap penting tapi sama sekali tidak dihargai oleh pimpinan (Resckhe, 2007). Pada dasarnya kepuasan kerja merupakan hal yang bersifat individual, setiap individu akan memiliki tingkat kepuasan yang berbeda-beda sesuai dengan sistim nilai yang berlaku pada dirinya. Masalah yang berkaitan dengan kepuasan kerja yang ada pada instansi ini adalah ketidak puasan karyawan didalam organisasi, contohnya karyawan sering merasa tidak puas terhadap sikap atasan, ditandai dengan seringnya karyawan komplen atas pekerjaan yang diberikan ataupun tidak merasa puas dengan keputusan atau tindakan yang dilakukan atasan dan ketika ditegur karena kesalahan, mereka tidak pernah mengindahkan teguran tersebut (Fitriastuti, 2013).

Sedangkan pada komitmen organisasi ini ditemukan masalah berupa kurangnya komimten organisasi karyawan, yang ditandai dengan persepsi karyawan bahwa mereka merasa jika sudah menjadi seorang pegawai negri itu sudah "aman". Dengan merasa aman karyawan bekerja secara santai, ada yang melakukan hal diluar tugasnya saat jam kerja seperti mengobrol, membaca koran dan bermain internet. Padahal jika ini dibiarkan terus menerus tentu akan membuat kinerja karyawan semakin memburuk dan organisasi tidak bisa memberikan pelayanan kepada masyarakat seperti yang diharapkan (Darmawati, 2013). 
Dalam penelitian ini, yang akan dibahas adalah Pengaruh Kepuasan Kerja dan Komitmen Organisasi terhadap Organizational Citizenship Behavior (OCB) pada Dinas Penanaman Modal dan Pelayanan Terpadu Satu Pintu (DPMPTSP) Kota Padang. Dipilihnya DPMPTSP Kota Padang dalam penelitian ini dikarenakan masih rendahnya perilaku OCB sehingga mempengaruhi kepuasan kerja serta komitmen dari pegawai.

Ada pun tujuan diadakan penelitian ini yaitu untuk menguji bagaimana masing-masing pengaruh kepuasan kerja, komitmen organisasi terhadap Organizational Citizenship Behavior (OCB) pada Dinas Penanaman Modal dan Pelayanan Terpadu Satu Pintu (DPMPTSP) Kota Padang.

\section{Pengembangan Hipotesis}

\section{Hubungan Kepuasan Kerja terhadap OCB}

Didukung oleh penelitian Rusmawati (2011) menunjukkan bahwa kepuasan kerja berpengaruh positif dan signifikan terhadap Organizational Citizenship Behavior (OCB) pada Kantor Pusat PT. BPD Bali. Berdasarkan indikator-indikator dalam variabel kepuasan kerja, maka hasil dari penelitian menjelaskan bahwa pengaruh kepuasan kerja terhadap Organizational Citizenship Behavior (OCB) pada Kantor Pusat PT. BPD Bali yaitu berpengaruh positif dan signifikan (Nurtjahjanti, 2011).

Berdasarkan berbagai hasil penelitian yang telah dijelaskan diatas, maka dapat dirumuskan hipotesis seperti berikut:

H1 : Diduga Kepuasan Kerja berpengaruh positif dan signifikan terhadap $O C B$.

\section{Hubungan Komitmen Organisasi terhadap OCB}

Didukung oleh penelitian Oemar (2011) menyebutkan bahwa model persamaan regresi linier berganda menunjukkan bahwa komitmen organisasi berpengaruh positif dan signifikan terhadap Organizational Citizenship Behavior (OCB) pegawai pada Bappeda Kota Pekanbaru, Pengaruh positif dan signifikan ini memberi arti bahwa apabila komitmen organisasi meningkat maka organizational citizenship behavior (OCB) pegawai dilingkungan Bappeda Kota Pekanbaru mengalami kecenderungan peningkatan pula (Oemar, 2013).

Berdasarkan berbagai hasil penelitian yang telah dijelaskan diatas, maka dapat dirumuskan hipotesis seperti berikut:

H2 : Diduga Komitmen organisasi berpengaruh positif dan signifikan terhadap $O C B$.

\section{METODE PENELITIAN \\ Jenis Penelitian}

Penelitian ini bersifat kuantitatif karena menggunakan data yang memerlukan perhitungan angka pada kuesioner dengan menggunakan skala likert dan menggunakan analisa kualitatif untuk menjelaskan deskripsi data data yang sudah diperoleh (Widyanto, 2013)

\section{Populasi dan Sampel}

Populasi yang akan diamati dalam penelitian ini adalah pegawai Dinas Penanaman Modal dan Pelayanan Terpadu Satu Pintu Kota Padang yang berjumlah 40 orang responden serta jumlah sample yang diambil dalam penelitian ini sama dengan jumlah populasi sehingga pada penelitian ini menggunakan metode total sampling untuk pengambilan sampel. 
HASIL PENELITIAN

Uji Asumsi Klasik

\section{Uji Normalitas}

One-Sample Kolmogorov-Smirnov Test

\begin{tabular}{ll|r}
\hline $\mathrm{N}$ & & Unstandardized Residual \\
\hline Normal Parameters $^{\mathrm{a}}$ & Mean & 40 \\
& Std. Deviation & .0000000 \\
Most Extreme Differences & Absolute & 3.39444995 \\
& Positive & .085 \\
Kolmogorov-Smirnov Z & Negative & .053 \\
Asymp. Sig. (2-tailed) & & -.085 \\
\hline
\end{tabular}

Sumber: Data Primer diolah dengan SPSS Th.2018

Berdasarkan hasil pengolahan data diatas terlihat bahwa nilai asymp.sig sebesar 0,934, yang mana nilai asymp.sig diperoleh 0,934>0,05. Maka dapat disimpulkan bahwa hasil uji normalitas kolmogrov-smirnov data tersebut terdistribusi normal karena nilai signifikan lebih besar dari 0,05 .

\section{Uji Multikolinearitas}

\begin{tabular}{|c|c|c|c|}
\hline \multicolumn{4}{|c|}{ Coefficients $^{\mathrm{a}}$} \\
\hline \multirow[b]{2}{*}{ Model } & & \multicolumn{2}{|c|}{ Collinearity Statistics } \\
\hline & & Tolerance & VIF \\
\hline \multirow[t]{3}{*}{1} & (Constant) & & \\
\hline & kepuasan_kerja & .954 & 1.048 \\
\hline & komitmen & .954 & 1.048 \\
\hline
\end{tabular}

Sumber: Data Primer diolah dengan SPSS Th.2018

Berdasarkan hasil pengolahan data diatas maka dapat dilihat bahwa masingmasing variabel independen memiliki nilai tolerance $>0.1$, dan masing-masing variabel independent VIF $<10$ berdasarkan hasil pengolahan data diatas maka dapat disimpulkan bahwa penelitian ini terbebas dari masalah Multikolinearitas.

\section{Uji Heteroskedastisitas}

Coefficients $^{\mathrm{a}}$

Model Sig.

\begin{tabular}{lll}
\hline 1 & (Constant) & .430 \\
& Kepuasan_kerja & .387 \\
& Komitmen_organisasi & .452 \\
\hline
\end{tabular}

Sumber: Data Primer diolah dengan SPSS Th.2018

Berdasarkan hasil uji heteroskedastisitas diatas dapat diketahui bahwa nilai signifikan variable kepuasan kerja adalah 0,387 dan komitmen organisasi sebesar 0,452 yang berarti nilai kedua variabel tersebut $>0,05$. Jadi dapat disimpulkan bahwa semua nilai dari variabel kepuasan kerja dan komitmen organisasi terbebas dari gejala heteroskedastisitas. 
Analisis Regresi Linier Berganda

\section{Hasil Uji Regresi Linear Berganda}

Coefficients $^{a}$

\begin{tabular}{|c|c|c|c|c|c|c|}
\hline \multirow[b]{2}{*}{ Model } & \multicolumn{2}{|c|}{ Unstandardized Coefficients } & \multicolumn{2}{|c|}{ Standardized Coefficients } & \multirow[b]{2}{*}{$\mathrm{t}$} & \multirow[b]{2}{*}{ Sig. } \\
\hline & B & Std. Error & Beta & & & \\
\hline (Constant) & .555 & 6.180 & & & .090 & .929 \\
\hline Kepuasan_kerja (X1) & .035 & .080 & & .040 & .443 & .660 \\
\hline Komitmen_organisasi (X2) & .605 & .065 & & .837 & 9.325 & .000 \\
\hline
\end{tabular}

Sumber : Data diolah SPSS

Berdasarkan hasil olah data diatas, maka dapat disusun persamaan regresi berganda sebagai berikut :

$\mathrm{Y}=0,555+0,035 \mathrm{x} 1+0,605 \times 2$.

Dari persamaan regresi di atas maka dapat diinterpretasikan beberapa hal antara lain :

1. Nilai konstanta persamaan di atas sebesar 0,555 Angka tersebut menunjukkan tingkat OCB bila tingkat Kepuasan Kerja dan Komitmen diabaikan.

2. Variabel Kepuasan Kerja memiliki nilai koefisien regresi sebesar 0,035. Nilai koefisien positif menunjukkan hubungan yang positif antara Kepuasan Kerja terhadap tingkat OCB. Hal ini berarti bahwa jika terjadi kenaikan variabel Kepuasan Kerja, maka nilai OCB akan mengalami peningkatan sebesar 0,035 dengan asumsi variabel independen yang lain dianggap konstan.

3. Variabel Komitmen organisasi memiliki nilai koefisien sebesar 0,605. Hal ini juga menunjukkan hubungan positif Komitmen organisasi terhadap OCB. Dapat disimpulkan bahwa jika terjadi kenaikan komitmen organisasi maka nilai OCB akan mengalami peningkatan sebesar 0,605 dengan asumsi variabel independen yang lain dianggap konstan.

4. Dari kedua nilai antara variabel Kepuasan Kerja dan Komitmen organisasi terdapat perbedaan dimana variabel Komitmen organisasi berpengaruh lebih besar terhadap OCB dibanding variabel kepuasan kerja.

\section{UJI T (Parsial)}

Hasil Uji T

\begin{tabular}{lcc}
\hline \multicolumn{1}{c}{ Model } & t & Sig \\
\hline Constant & 0,090 & 0,929 \\
\hline Kepuasan kerja & 0,443 & 0,660 \\
\hline Komitmen Organisasi & 9.325 & 0,000 \\
\hline
\end{tabular}

Sumber : Data diolah SPSS

Berdasarkan hasil pengolahan data uji $\mathrm{t}$ parsial diatas, maka dapat disimpulkan bahwa :

1. Dari tabel diatas terlihat bahwa kepuasan kerja memiliki nilai koefisien regresi positif dengan nilai t hitung sebesar 0,443 dengan nilai sig sebesar 0,660. Jika dibandingkan dengan ( $\mathrm{t}$ tabel, sig 0.05, df $(40-3)=37$ ). Maka dapat terlihat bahwa dengan nilai t hitung $0,443<\mathrm{t}$ tabel 1,687 , dan nilai sig $0,660>0.05$, maka dapat disimpulkan bahwa H0 diterima dan $\mathrm{H} 1$ ditolak 
artinya bahwa kepuasan kerja tidak berpengaruh dan tidak signifikan terhadap OCB.

2. Dari tabel diatas terlihat bahwa komitmen organisasi memiliki nilai koefisien regresi positif dengan nilai t hitung sebesar 9.325 dengan nilai sig sebesar 0,000. Jika dibandingkan dengan ( t tabel, sig 0.05, df $(40-3)=37$ ). Maka dapat terlihat bahwa dengan nilai t hitung 9.325 > t tabel 1,687 dan nilai sig $0,000<0.05$, maka dapat disimpulkan bahwa $\mathrm{H} 1$ diterima dan $\mathrm{H} 0$ ditolak artinya bahwa komitmen organisasi berpengaruh dan signifikan terhadap OCB.

Berdasarkan hasil penelitian mengenai Pengaruh Kepuasan Kerja dan Komitmen Organisasi terhadap Organizational Citizenship Behavior (OCB) pada Dinas Penanaman Modal dan Pelayanan Terpadu Satu Pintu (DPMPTSP) Kota Padang, maka pembahasan dapat diberikan sebagai berikut:

1. Pengaruh Kepuasan Kerja terhadap Organizational Citizenship Behavior

Kepuasan kerja adalah suatu efektifitas atau respon emosional terhadap berbagai aspek pekerjaan. Ini berarti instansi menggambarkan adanya tingkat produktifitas yang tinggi dengan kepuasan kerja pegawai yang bekerja di dalamnya. Oleh karena itu Hasil pengujian yang didapat antara variabel Kepuasan Kerja terhadap variabel OCB menunjukkan tingkat signifikannya $>0,05$, maka $\mathrm{H} 0$ diterima dan $\mathrm{H} 1$ ditolak, sedangkan dilihat dari t hitung < t tabel, maka $\mathrm{H} 0$ diterima dan menolak H1 yang berarti variabel Kepuasan kerja tidak berpengaruh dan tidak signifikan terhadap Organizational citizenship behavior (OCB).

Hasil Penelitian ini diperkuat oleh penelitian yang dilakukan oleh (Wibowo, 2013) yang berjudul pengaruh antara komitmen organisasional dan kepuasan kerja terhadap Organizational Citizenship Behavior pada karyawan PT. Telkom Purwokerto. Populasi penelitian ini berjumlah 100 orang dan sampel penelitian berjumlah 42 orang. Penelitian ini menyebutkan bahwa model regresi menunjukan Kepuasan kerja tidak berpengaruh dan tidak signifikan terhadap Organizational Citizenship Behavior dilingkungan PT. Telkom Purwokerto (Wibowo, 2018).

Penelitian ini juga didukung dengan penelitian yang dilakukan oleh (Utomo, 2001) yang berjudul pengaruh hubungan organizational citizenship behavior (OCB), komitmen dan kepuasan kerja terhadap kecenderungan pimpinan transaksional dan transformasional (Studi pada Kantor Pemerintah Daerah Tk.II Kabupaten Kebumen Jawa Tengah). Alat yang digunakan dalam penelitian ini adalah analisis Structural Equation Modelling (SEM) yang dapat disimpulkan, penelitian ini menyebutkan bahwa variabel kepuasan kerja tidak berpengaruh secara signifikan terhadap organizational citizenship behavior (Fauziyah, 2010).

Berdasarkan hasil deskriptif dan pengujian regresi di atas, dapat dinyatakan meskipun rata-rata tingkat kepuasan kerja yang dirasakan pegawai cukup tinggi, akan tetapi tidak mempengaruhi tingkat OCB pegawai di lingkungan Dinas Penanaman Modal dan Pelayanan Terpadu Satu Pintu Kota Padang.

2. Pengaruh Komitmen terhadap Organizational Citizenship Behavior

Komitmen organisasi cenderung didefenisikan sebagai suatu perpaduan antara sikap dan perilaku. Ini berarti pegawai yang komit terhadap organisasi akan menunjukan sikap dan perilaku yg positif terhadap instansinya, serta memiliki keyakinan yang pasti untuk membantu 
mewujudkan tujuan perusahaan. Oleh karena itu hasil pengujian yang didapat antara variabel Komitmen organisasi terhadap variabel OCB menunjukkan tingkat signifikannya $<0,05$, maka H0 ditolak dan H1 diterima, sedangkan dilihat dari t hitung $>\mathrm{t}$ tabel, maka H0 ditolak dan menerima $\mathrm{H} 1$ yang berarti variabel Komitmen organisasi berpengaruh dan signifikan terhadap Organizational citizenship behavior (OCB).

Dari hasil penelitian yang dilakukan, hal ini dipengaruhi oleh indikasi bahwa karyawan yang memiliki loyalitas dan komitmen akan berusaha semaksimal mungkin untuk mencapai tujuan perusahaan dengan bertanggung jawab atas segala pekerjaan dan aktif mencari informasiinformasi penting yang berguna bagi perusahaan karena telah memiliki keterikatan emosional dengan perusahaan sehingga dengan rela dan ikhlas melakukan perilaku ekstra seperti membantu rekan kerja lain yang membutuhkan tanpa mengharapkan imbalan (Kurniawan, 2015).

Hasil penelitian ini diperkuat oleh penelitian yang dilakukan oleh (Oemar, 2013) yang berjudul Pengaruh Budaya Organisasi, Kemampuan Kerja dan Komitmen Organisasi terhadap Organizational Citizenhsip Behavior (OCB) Pegawai pada BAPPEDA Kota Pekanbaru menyebutkan bahwa model persamaan regresi linier berganda menunjukkan komitmen organisasi berpengaruh positif dan signifikan terhadap Organizational Citizenship Behavior (OCB) pegawai pada Bappeda Kota Pekanbaru, Pengaruh positif dan signifikan ini memberi arti bahwa apabila komitmen organisasi meningkat maka organizational citizenship behavior (OCB) pegawai dilingkungan Bappeda Kota Pekanbaru mengalami kecenderungan peningkatan pula (Oemar, 2013).

Penelitian juga didukung oleh penelitian yang dilakukan oleh (Prita, 2010) dengan judul pengaruh hubungan komitmen terhadap organisasi dengan Organizational Citizenship Behavior (OCB) Pada Pegawai Negeri Sipil di Biro Organisasi Dan Kepegawaian Setda Provisnsi Jawa Tengah, dengan menggunakan analisis teknik korelasi Product Moment. Penelitian ini menyebutkan bahwa Terdapat pengaruh positif dan signifikan komitmen organisasi terhadap Organizational Citizenship Behavior (Hidayat, 20014).

\section{KESIMPULAN}

Berdasarkan hasil pengujian dan pembahasan mengenai pengaruh kepuasan kerja dan komitmen organisasi terhadap organizational citizenship behavior (OCB) pada Dinas penanaman modal dan pelayanan terpadu satu pintu (DPMPTSP) Kota Padang, maka dapat ditarik kesimpulan, antara lain:

1 Dari tabel diatas terlihat bahwa Kepuasan kerja memiliki nilai koefisien regresi positif dengan nilai thitung $0,443<\mathrm{t}$ tabel 1,687 serta nilai sig 0,660 $>0,05$. Dapat disimpulkan bahwa dilihat dari tingkat signifikannya $>0,05$, maka $\mathrm{H} 0$ diterima dan $\mathrm{H} 1$ ditolak, sedangkan dilihat dari $\mathrm{t}$ hitung $<\mathrm{t}$ tabel, maka $\mathrm{H} 0$ diterima dan menolak $\mathrm{H} 1$ yang berarti variabel Kepuasan kerja tidak berpengaruh dan tidak signifikan terhadap Organizational citizenship behavior (OCB).

2 Dari tabel diatas terlihat bahwa Komitmen organisasi memiliki nilai koefisien regresi positif dengan nilai t hitung sebesar 9,325 > t tabel 1,687 dengan nilai sig sebesar $0,000<0,05$. Dapat disimpulkan bahwa dilihat dari tingkat signifikannya $<0,05$, maka $\mathrm{H} 0$ ditolak dan $\mathrm{H} 1$ diterima, sedangkan dilihat dari t hitung > t tabel, maka $\mathrm{H} 0$ ditolak dan menerima $\mathrm{H} 1$ yang 
berarti variabel Komitmen organisasi berpengaruh positif dan signifikan terhadap Organizational citizenship behavior (OCB).

\section{UCAPAN TERIMA KASIH}

Dengan selesainya artikel penelitian Bapak Febryandhie Ananda, SE, M.Si selaku Ketua STIE "KBP" Padang yang telah memberikan bimbingan dan fasilitas selama penulis menjadi mahasiswi. Ibu Lidhya Marta, SE, MM selaku Wakil Ketua STIE “KBP” Padang. Ibu Febsri Susanti, SEI, MM selaku Ketua Program Studi Manajemen di STIE “KBP” Padang. Ibu Maria Magdalena, SPd,M.M selaku Dosen Pembimbing Akademik Program Studi Manajemen di STIE "KBP” Padang. Ibu Zusmawati, SE, MM selaku Dosen Pembimbing Skripsi dan artikel yang telah bersedia meluangkan waktu untuk membimbing dalam penulisan penelitian ini. Semua Guru, Dosen, dan Staff yang telah berbagi ilmu dan waktunya sehingga membantu penulis menjadi orang yang memiliki ilmu dan dapat menyelesaikan tugas akhir ini. Ibu Siti Dian Harlinda Rias, SH, MM selaku Kepala Sub Bagian Umum Dinas Penanaman Modal dan Pelayanan Terpadu Satu Pintu Kota Padang yang telah memberi izin penulis untuk melakukan penelitian serta membantu penulisan didalam memperoleh data.

\section{DAFTAR PUSTAKA}

Agustina, L. (2009). Pengaruh konflik peran, ketidak jelasan peran dan kelebihan peran terhadap kepuasan kerja dan kinerja auditor pada KAP wilayah DKI Jakarta. Jurnal Akuntansi, 1(1), 40-69.

Ayu, P. Rahmizal, M. (2018). Impact of unbalanced economic growth to dynamic trade specialization. Theoretical \& Applied Economics 25 (3)

Darmawati, A. (2013). Pengaruh kepuasan kerja dan komitmen organisasi terhadap organizational citizenship behavior karyawan Fakultas Ilmu Sosial dan Ekonomi Universitas Negeri Yogyakarta. Jurnal Economia, 9(1), 10-17.

Djati, S. P. (2017). Pengaruh kepuasan kerja dan komitmen organisasi terhadap organizational citizenship behavior (OCB) (Studi Kasus RSU UKI). Fundamental Management Journal, 1(1), 40-53.

Dila, T. R., \& Zusmawati, Z. (2019). Pengaruh Kemampuan Kerja Dan Motivasi Kerja Terhadap Kinerja Pegawai Dinas Penanaman Modal Dan Pelayanan Terpadu Satu Pintu (DPMPTSP) Kota Padang. https://doi.org/10.31219/osf.io/ks5vy

Dona, E. (2016). Pengaruh Perencanaan, Prosedur Dan Pengawasan dan Komitmen Organisasi Dalam Pelaksanaan Anggaran Terhadap Kinerja Pegawai Dinas Pekerjaan Umum Kota Pariaman. Jurnal Riset Manajemen dan Akuntansi (Jurmak), 23-35.

Dona, E. (2018). Analisis Motivasi Kerja Ditinjau Dari Lingkungan Kerja Kasus Karyawan LBPP Lia Payakumbuh. Jurnal KBP.

Fauziyah, M. (2010). Pengaruh kepuasan kerja dan komitmen organisasi terhadap organizational citizenship behavior (OCB) pegawai pada Komplek Pendidikan Muhammadiyah Gadung Surabaya. Jurnal Metode Penelitian Kuantitatif, 7(305), 98-134.

Fitriastuti, T. (2013). Pengaruh kecerdasan emosional, komitmen organisasional dan Organizational Citizenship Behavior (OCB) terhadap kinerja Pegawai Negeri Sipil Organisasi Perindustrian dan Perdagangan Kabupaten Kutai Timur. Jurnal Dinamika Manajemen, 4(2), 103-114.

Hidayat, A. (2014). Pengaruh komitmen organisasi dan kepuasan kerja terhadap 
Organizational Citizenship Behavior (OCB) di PT. Argamukti Pratama Semarang. Jurnal Publikasi Ilmiah, 9(18), 1-15.

Ismiati, N., \& Zusmawati, Z. (2019). Pengaruh Konflik Peran Ganda Dan Stres Kerja Terhadap Kinerja Polisi Wanita Di Polresta Padang. https://doi.org/10.31219/osf.io/yfjrb

Koesmono. (2005). Pengaruh budaya organisasi terhadap motivasi dan kepuasan kerja serta kinerja karyawan pada Sub Sektor Industri Pengolahan Kayu Skala Menengah Di Jawa Timur. Jurnal Manajemen dan Kewirausahaan, 7(2), $162-179$.

Kurniawan, A. (2015). Pengaruh komitmen organisasi terhadap organizational citizenship behavior PT X Bandung. Jurnal Manajemen, 15(1), 95-118.

Lubis, A. Y. O., \& Susanti, F. (2019). Pengaruh Gaya Kepemimpinan Dan Kompensasi Terhadap Prestasi Kerja Karyawan (Studi pada PT Japfa Comfeed Indonesia (JCI) Tbk Devisi Fam 1. https://doi.org/10.31227/osf.io/7tbrg

Margaretha, M. (2012). Pengaruh servant leadership terhadap komitmen organisasi dan organization citizenship behavior pada perpustakaan UKM Bandung. Jurnal Manajemen, 11(2), 189-206.

Mayliza, R. (2019). Pengaruh Gaya Kepemimpinan Dan Disiplin Kerja Terhadap Kinerja Pegawai, Dengan Motivasi Kerja Sebagai Variabel Intervening (Studi Pada Dinas Pendidikan Kabupaten Tanah Datar). https://doi.org/10.17605/OSF.IO/JGPDN

Mayliza, R. (2019). Pengaruh Kecerdasan Spiritual Terhadap Kinerja Karyawan Biro Quality Assurance PT. Semen Padang. https://doi.org/10.17605/OSF.IO/GQC6R

Mayliza, R. (2019). Pengaruh Stres Kerja Dan Kesempatan Promosi Terhadap Turnover Intention Pada CV. Anisa Fadly Kabupaten Padang Pariaman. https://doi.org/10.17605/OSF.IO/PCDV2

Mayliza, R. (2019). Pengaruh Good Corporate Governance Dan Leverage Terhadap Kinerja Keuangan Pada Perbankan Yang Terdaftar Di BEI. https://doi.org/10.17605/OSF.IO/M9DT6

Mayliza, R. (2019). Pengaruh Kepuasan Kerja Dan Loyalitas Kerja Terhadap Organizational Citizenship Behavior (OCB) Pada Pegawai BPKPAD Di Madina. https://doi.org/10.17605/OSF.IO/5PVWB

Minadaniati, L. (2012). Pengaruh kepuasan kerja dan iklim organisasi terhadap organizational citizenship behavior (OCB) karyawan pada PT. Trubus Swadaya. Jurnal Riset Manajemen Sains Indonesia (JRMSI), 3(1), 1-16.

Muna, N. (2012). Pengaruh kepuasan gaji dan komitmen organisasi terhadap intensi turnover pada Divisi PT. Jamsostek. Jurnal Riset Manajemen Sains Indonesia (JRMSI), 3(1), 1-19.

Nardo, R. Evanita, Syahrizal, S. (2018). Pengaruh Kepemimpinan Transformasional, Dan Lingkungan Kerja Non Fisik Terhadap Perilaku Inovatif. JEBI (Jurnal Ekonomi dan Bisnis Islam) 3 (2), 209-215

Nardo, R. Evanita, Syahrizal, S. (2019). The Effect of Transformational Leadership and Non Physical Work Environment on Innovative Behavior with Work Motivation as a Mediation For Employees of Tour And Travel Companies In West Sumatera. 2nd Padang International Conference on Education, Economics, Business and Accounting (PICEEBA-2 2018)

Oemar, Y. (2013). Pengaruh budaya organisasi, kemampuan kerja dan komitmen organisasi terhadap Organizational Citizenhsip Behavior ( OCB ) Pegawai 
pada BAPPEDA Kota Pekanbaru. Jurnal Aplikasi Manajemen, 11(1), 65-76.

Putrana, Y. (2016). Pengaruh kepuasan kerja dan komitmen organisasi terhadap organizational citizenship behavior dalam meningkatkan kinerja karyawan pada PT. Gelora Persada Mediatama Semarang. Journal Of Management, 2(2), 1-14.

Rahmizal, M. (2018). Analysis of Indonesia Marine Fisheries with Economic Growth, Population and Effort Effectiveness. European Journal of Engineering and Formal Sciences 1 (1), 65-70

Rahmizal, M. (2018). Pengaruh Pendapatan, Pendidikan, Kesehatan, Modal Sosial Dan Religiusitas Terhadap Kebahagiaan Individu Di Indonesia. Universitas Gadjah Mada

Rahmizal, M. (2017). Analysis of Indonesia Marine Fisheries with Economic Growth, Population and Effort Effectiveness. European Journal of Engineering and Formal Sciences 1 (1), 17-22

Riana, I. G. (2014). Pengaruh kepuasan kerja terhadap komitmen organisasional dan kualitas layanan karyawan pada Hotel Bali Hyatt Sanur. Jurnal Manajemen Strategi Bisnis Dan Kewirausahaan, 8(1), 68-80.

Ridho, M., \& Susanti, F. (2019). Pengaruh Stres Kerja Dan Motivasi Kerja Terhadap Kepuasan Kerja Pada Karyawan Bank Mandiri Syariah Cabang Padang. https://doi.org/10.31227/osf.io/pa2cg

Susriyanti, S. Nardo, R. (2019). Pengaruh Fungsi Komunikasi Dan Kepuasan Kerja Karyawan Terhadap Pemberian Pelayanan Nasabah PT. BPR LPN Talawi Sakato. Jurnal Administrasi Sosial dan Humaniora 3 (2), 97-111.

Seniati. (2004). Pengaruh kepribadian dan komitmen organisasi terhadap organizational citizenship behavior pada perampingan organisasi perusahaan industri. Jurnal Makara,Sosial Humaniora, 8(3), 105-111.

Soegandhi, V. M. (2013). Pengaruh kepuasan kerja dan loyalitas kerja terhadap organizational citizenship behavior pada karyawan PT. Surya timur sakti Jatim. Jurnal Agora, 1(1).

Sutanto, E. M. (2013). Pengaruh motivasi kerja dan kepuasan kerja terhadap komitmen organisasional karyawan PT. DAI knife di Surabaya. Jurnal Agora, 1(3), 1-9.

Ticoalu, L. K. (2013). Pengaruh organizational citizenship behavior (OCB) dan komitmen organisasi terhadap kinerja karyawan pada PT. Bank Tabungan Pensiunan Nasional. Jurnal EMBA, 1(4), 782-790.

Tobing, D. S. K. L. (2009). Pengaruh komitmen organisasional dan kepuasan kerja terhadap kinerja karyawan PT . Perkebunan Nusantara III di Sumatera Utara. Jurnal Manajemen dan Kewirausahaan, 11(1), 31-37.

Triyanto, A. (2009). Organizational Citizenship Behavior ( OCB ) dan pengaruhnya terhadap keinginan keluar dan kepuasan kerja karyawan pada Resort Kantor Kepolisian Jawa Barat. Jurnal Manajemen, 7(4), 1-13.

Wibowo, A. (2018). Pengaruh komitmen organisasional dan kepuasan kerja terhadap organizational citizenship behavior (OCB) pada PT. Telkom Purwokerto. Psycho Idea, 1(16), 51-58.

Widyanto, R. (2013). Pengaruh kepuasan kerja terhadap organizational citizenship behavior melalui komitmen organisasi karyawan cleaning service di ISS Surabaya. Jurnal Hospitality Dan Manajemen Jasa, 1(1), 1-15..

Yudistira, D. S., \& Susanti, F. (2019). Pengaruh Motivasi Kerja Dan Budaya Kerja Terhadap Kinerja Karyawan Dinas Pemberdayaan Masyarakat Dan Desa, Pengendalian Penduduk Dan Keluarga Berencana Kabupaten Pesisir Selatan. 
https://doi.org/10.31227/osf.io/jk54m

Zusmawati, Z \& Hasdi, D. E. (2019). Pengaruh Karakteristik Pekerjaan Dan Stress Kerja Terhadap Kinerja Karyawan Bidang Tp-Op Dinas Psda Prov Sumbar. https://doi.org/10.31219/osf.io/ev6w4 